\title{
Animism is Applied Ethnobotany: A Shamanic Healing Ritual with the Dayak Benuaq Ohookng / East Kalimantan
}

\author{
Herwig Zahorka \\ German Forestry Director Ret., Bogor, Indonesia \\ Corresponding email \\ zahorka.herwig@gmail.com
}

\begin{abstract}
The Dayak Benuaq Ohookng people believe in many and diverse territorial ghosts/spirits (wook) who exist in the environment, some of which have the power to remove the soul (juus) of a human body part or organ and, at the same time, implant disease. Consequently, this body part or organ gets sick. The mission of the shamans (pembeliatn), as mediums to the spiritual world, is to identify the ghost/spirit responsible during nocturnal rituals and to submit all of the diverse ritual offerings possible, including making an exchange of a "soul" (kelakar) made from ironwood (Eusideroxylon zwageri). To get rid of the disease, the patient smears some of his/her own saliva onto a carved statue (sepatukng silih), depicting the ghost/spirit concerned, after the shaman activated it. Later, this statue is taken to the forest. The shaman can also extract the disease from the sick body part by help of a thinly spliced banana leaf (telolo). The disease can also be attached to the statue or put into the blood of sacrificial animals. In order to finally find and identify the lost soul of the patient's sick body part, the shaman performs a vigorous dance and then falls into a trance, during which he receives a message about where to catch the soul. To discover the soul and capture it, he uses a bamboo stick filled with boiled rice (tolakng tintikng). The captured soul is then massaged into the sick body part of the patient. To perform this ritual, a great number of traditional and institutionalized plants are essential. They are arranged around the altar (balai sianca jadi) and used for ritual objects. White rice and rice colored with black, red, yellow and green dyes plays an important role in attracting and satisfying the ghosts.
\end{abstract}

Keywords: Animism, Borneo, Dayak, Eusideroxylon zwageri, ritual, shaman

\section{INTRODUCTION}

The Dayak Benuaq Ohookng referred to in this article are settlers of the longhouse villages of Pentat, Lempunah, Muara Nayan, Mancong and the former Keranau, all situated along the Ohong (Ohookng in their language) River, and of the Tanjung Isui area in Kecamatan Jempang, Kutai Barat, East-Kalimantan. Culturally and linguistically, they belong to the Dayak Luangan group (Sillander, 1995).

In their traditional beliefs, a living human has a spirit soul (semangat) and in addition, seven body-part souls (juus). The head has the juus puaq, the abdomen the juus sentunkng, the heart has the juus lemposu, the bones have the juus tulakng, the flesh the juus issi, and each eye has an ilang anak majang. Diverse terrestrial ghosts or spirits (wook) have the power to "eat" the juus of a human body part or organ and, at the same time implant a disease. Consequently, this body part or organ gets sick. Efforts to cure such diseases can be 
successful only if the disease of the body part or organ is removed and the missing juus is replaced.

This is the mission of the shamans, pembeliatn or beliatn, who act as mediums to the spirits/ghosts or wook. During nocturnal sessions, generally performing the rites of belian sentiu, (also sentiyu), these mediums have to identify the wook responsible for the illness and to submit all the diverse ritual offerings, including a small-carved statue, the "exchange soul" or kelakar, made of ironwood (Eusideroxylon zwageri).

If the identified wook agrees, he will take back the disease. To get the missing juus back to the patient, the beliatn performs a furious dance and falls into a trance. In this state, he gets inspiration from the wook about where to find and catch the juus for re-implantation into the patient's body.

A belian sentiu ritual can generally last up to four nights, with enhancing activities and increasing amounts of ritual equipment. To perform this type of ritual, a great number of traditional and institutionalized plants and offerings, or ramuan, are essential, and every one of them has a special function or is associated to a category of wook. Many are medicinal plants (Susiarti, 2005). Up to 59 species of 32 botanic families are used in shamanistic rituals (Gönner, 2002).

\section{REQUIREMENTS FOR THE HEALING PERFORMANCE}

\section{The Altar, or Balai Sianca Jadi and the Shaman's Protective Measures}

To perform a belian ritual a rectangular-shaped altar or shrine balai sianca jadi (Figure 1) is constructed from potukng wood (Melicope incana, syn. Euodia alba, Rutaceae). This is the type of wood related to many wook. The altar furniture includes small wooden houses for the wook, two antaakng (Tempayan, antique Chinese jars, home of spirits), a genikng (big antique gong, also home to a spirit), a short ladder, and a specific superstructure. The altar is surrounded by high stalks or branches of the following eight-obligatoriqe plant species (eight is an important number in belian rituals):

1. Jelmoq (Pisang, Banana), Musa paradisiaca L., Musaceae

2. Sepootn (Pinang), Areca catechu L., Palmae

3. Touq, Costus sp., Zingiberaceae

4. Ukor, Cariota mitis Loureiro, Palmae

5. Biowo, Cordyline fruticosa (L.) A. Chevalier, Liliaceae

6. Teluyatn (Ironwood), Eusideroxylon zwageri Teysm. \& Binnend., Lauraceae

7. Potukng, Melicope incana T.G.Hartley, Rutaceae, Syn. Euodia alba Hook.f.

8. Nancakng, Macaranga triloba (Blume) Muell. Arg., Euphorbiaceae

Of the two most important of these items, teluyatn, Eusideroxylon, and potukng, Melicope, two specimens are present. These plant species are related to distinct wook families. Their wood is always used with ritual performances and worked into ritual objects. Potukng, rich in alkaloids, it is the "spirits' wood". Teluyatn, also called belian, incorporates mystic power and calls helpful spirits. (Figure1). The Balai Sianca Jadi altar with the Awiir fabric).

The beliatn has to be successful to lure all the various wook from the forest, the field, the trees and the waterside into the room so that they get access to the offerings and become supportive. When the altar is beautifully decorated, then the wook will settle on the branches of the plants or in the small houses. The bowls and plates containing offerings are crowned 
with a cone made from young leaves of the coconut tree. The fringed panels on the side of the room are made of the same material. Special fringes and objects intended to attract spirits are made of the young leaves of tuak, the Aren Palm Arenga pinnata (Wurmb.) Merill. Ornamental fringes in red and yellow are often from the young leaves of paleh (also palas), a small palm, Licuala sp. that keeps evil wook away.

To get the attention of the spirits, the acting beliatn starts the Séance with a sharp whistle produced from the hollowed fang of the sunbear (Helarctos malayanus). To protect himself of malefic wook he besmears his front, neck, chest, and arms with white rice paste and sprinkles himself and all of the people in the room with fragrant danum bungaq mayang (danum = water and bungaq mayang = the flower of sepootn or the Areca catechu). For sprinkling, he uses a small twig of ngeraseh, which is basil (Ocimum basilicum L., Caesalpiniaceae). This "holy-water" ritual seems to be part of an ancient Hindu heritage from the Mulawarman and following Kingdoms, which existed in this area until the arrival of Islam. It produced the first stone inscriptions in Sanskrit with Pallava letters in the region now known as Indonesia at about 350 AD. This assumption may also apply to the use of incense at the beginning of the ritual. Small pieces of tuber root from the luaq or luwee plant, (Dianella ensifolia (L.) DC., Liliaceae), which contains an insecticide, are heated in a small pan over glowing charcoal. Also, raisin incense can be used.

Finally, the beliatn throws wajiq yellow sacral rice over his shoulder toward the direction to the entrance three times. This ritual calls the rice spirit lolakng luikng (lolakng means "beautiful woman"). This female spirit, which seems to be of ancient Hindu origin, transmits the messages between the beliatn and his helpers, the mulukng spirits. The yellow dye for the rice is kunyit, extracted from the rhizome of Curcuma longa L., Zingiberaceae. Yellow dye is also extracted from siraakng, which is Codiaeum variegatum (L.) B1., Euphorbiaceae.

The most effective defense weapon of the beliatn against dangerous wook, however, is his "leaf sword", the biowo. It is a leaf of the Cordyline fruticosa (L.) A. Chevalier, Liliaceae, artfully decorated with cuts and tied young leaves of the coconut tree (Figure 2). The crown and the cuffs of the beliatn are made of the same material. The people plant biowo plants in their garden and in the fields to keep evil spirits away.

Then, in long-lasting songs in a euphemistic and poetic language called mempakn beliatn, the beliatn calls all the spirits and ghost families by their names and recounts all the offerings ready for them.

\section{Awiir, the Shaman's Spiritual Link to the World of Spirits/Ghosts}

With the biowo in his hand, the beliatn dances in a counterclockwise direction around a white or patterned long cloth, which is hanging from the ceiling. At the top, this fabric is decorated with hanging young green inflorescences from sepootn, the Pinang Palm (Areca catechu L.), as well as some ornamental palm leaves. This is the awiir, the most sacred attribute of each Belian ritual (Figure 1, Figure 2). It is the vehicle of the medial beliatn, linking him to the world of the spirits and reverse. By this, his semangat will journey upwards into the realm of the spirits. Hidden at the top is a wooden cross within a ring. This symbolizes the crossroad leading the beliatn to the eight levels of skies where the spirits live in their villages. 


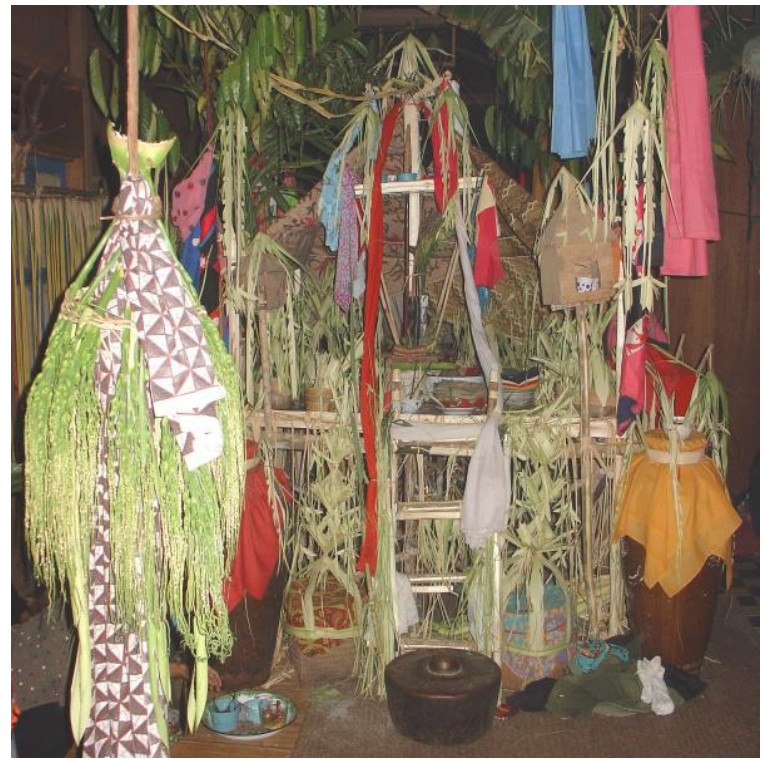

Figure 1. The Balai Sianca Jadi altar with the Awiir fabric

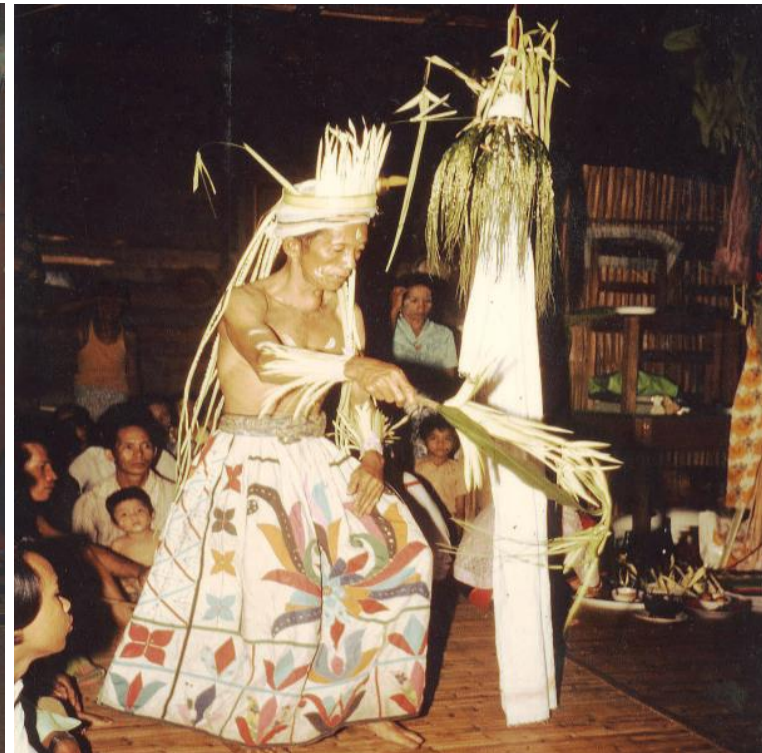

Figure 2. Beliatn Moya performing Belian Sentiu Ritual

One after another, all offerings are placed at the foot of the awiir and the beliatn presents them singing to the spirits with devote gestures. This is also the place where the beliatn strives for enlightenment to identifying the wook responsible for the disease. To help him achieve enlightenment, the shaman's small pots contain bee wax torches, a small mirror, rice and twigs from siraakng, Codiaeum variegatum, whose green leaves are spotted with yellow marks that look like yellow sacral rice. This medicinal plant has a magical significance because it is considered immortal. Often it is planted on graves. Even if all signs of the grave vanish after several decades, Codiaeum will still be growing there to mark the spot. Any primitive effort of vegetative propagation is always successful.

All performances and activities of the beliatn are accompanied by the sounds of several booming gimar drums, the genikng big gongs, and six small kentangan or saron gongs, which play the melody. Rhythm and melody vary according to the action of the beliatn.

\section{Tempting Food Offerings and Exchange Souls for the Spirit}

The most important alluring food for the wook is boiled white rice together with boiled rice colored with black, red, yellow and green dyes. This "five-color-rice" fills dozens of hanging and standing platforms. The black dye is extracted from the leaves of sopaakng piaq, which is the Leguminosa Archidendron sp. The red dye comes from the fruits of gelinapm (also gilinggam), Bixa orellana L., Bixaceae. The yellow dye comes from komaat, Codiaeum variegatum L., Euphorbiaceae and kunyit, which is from the root of the Curcuma longa L., Zingiberaceae. Finally, the green dye is derived from the leaves of puput, Jasminum sambac Aiton, Oleaceae, or from the leaves of biowo, Cordyline fruticosa.

Small platforms in front of the house constructed with potukng wood and loaded with five-color rice are intended to lure the wook into the house (Figure 3, Pentat 2006). At the center of the plate with the colored rice are red petals for decoration. The posts of the left platform are pointed like the hats the most powerful ghosts are generally depicted with. To accommodate a great number of wook, particularly the nyahuq omen spirits in the room, swing-shaped constructions kelengkakng eboq (kelengkakng = swing) with many "sitting 
boards", one on top of the other, hang from a beam. Each storey of the swings harbors a banana leaf covered with the five-color rice.

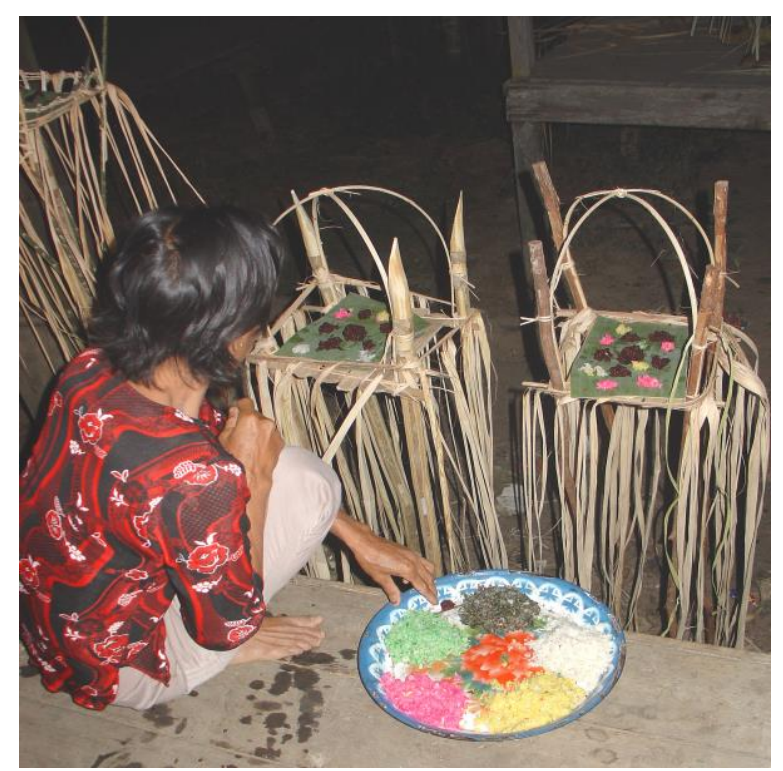

Figure 3. Rice with the five colors for the spirits

Some beliatn offer the colors additionally in liquid form, particularly to the juata water spirits. The four glasses of colored liquid are accompanied by four-sepatukng kokooq, dog-like figures carved of potukng wood (sepatukng $=$ statue, $k o k o o q=\operatorname{dog}$ ). The white color appears in the white rice at the center. The purpose of this set of offerings is probably to attract the wook from all four points of the compass. This idea could also originate from ancient Hindu influence, as the four directions play an important role in Hinduism.

A big dog-shaped figure on the side of the belian depicts the timang (tiger), a spirit protecting the beliatn, which is also carved out of potukng wood. The figure is generally carefully dressed with a typically Benuaq ikat fabriq ulap doyo woven from the fibers of the leaves of doyo, Curculigo latifolia Dryander, Amaryllidaceae. Figures and statues, which depict or attract wook, or which should be occupied by a wook have to be made of potukng wood. Mostly these figures take a human-like shape.

Other, similar, carved figures, which are made of ironwood, teluyatn, Eusideroxylon zwageri, have an entirely different function. These are the exchange souls, the kelakar. Several of them are generally displayed within the altar area and each is designated as a compensation (ganti) or exchange soul for a patient. They are offered without a special ritual. Their length can differ; however, they always show their sex: the male with loincloth, the female with skirt. The kelakar can be considered a symbolic substitute for a human sacrifice, a simulacrum.

\section{Some of the Spirits/Ghosts the Beliatn have to deal with}

While the spirits originally worshipped by adherents of an archaic animism are located in and belong to individual animals, plants, natural phenomena and ritual objects (Zahorka, 2004), the spirits of the Benuaq roam the natural environment. They are not the spirits of individual plants or animals, but they are associated with trees, forests, mountains, swamps, water, fields or villages. They are territorial spirits. Most of them are generally benevolent if rewarded by the beliatn with adequate offerings. 
A helpful sky spirit associated with (former) headhunting raids (and so with the color of red) is nayuq. He controls the keeping of the adat (customary) rules and is an aid to the beliatn, as is the timang spirit during Belian rituals. However, both punish people, who disregard the adat, with sicknesses. The mediating friendly rice spirit, lolakng luikng, has already been mentioned.

A group of generally good spirits, which the beliatn asks for aid, is the tangkai. The helpful mulukng (already mentioned) belong to them, as do the juata water spirits, the madakng, the nyahuq and the tonoi. The juata spirits are associated with the rainbow, with pregnancy and delivery, but they are also responsible for diarrhea and dysentery. The madakng are mountain spirits that can create body pain. The nyahuq are associated with the omen birds and with puti that is the Mangris tree Koompassia excelsa (Becc.) Taub., Caesalpiniaceae. The nyahuq also lead the soul of the deceased to the other world. The tonoi earth spirits guard the village and the ritual objects like the gongs, the tempayan and the mandaus. They are not as powerful as the others are, but they are the protective spirits in the village, and are associated with the color white. The kuyakng are tree spirits associated with the color green and with the Waringin tree nunuq ringin, a strangling fig, Ficus benyamina L., Moraceae. These spirits can cure, and they can even influence life expectancy, though, they also can create madness.

The great varieties of mountain and forest spirits that are called wook are associated with the color black. They include the mulaakng family who can abduct a juus if not rewarded with adequate offerings. This family is associated with the deraya sepatukng tree, which is Horsfieldia grandis, Myristicaceae.

Specified as evil are the spirits known as the banci, the bongai and the tentowijaq. The Banci, a powerful female wook, is responsible for many severe diseases like malaria and encephalitis. There are some remarkable parallels between the banci and the Bali-Hindu witch Rangda. To pacify her, a great variety of offerings and blood are needed. Bongai and tentowijaq are powerful forest wook that can create a bulk of various diseases by abducting human juus. To attempt them to return a juus, the blood of sacrificed animals is obligatory. Unspecified groups of evil spirits are also called papaq or papaiq. Local variations exist.

\section{Attracting and Luring the Spirits to Enter and the Diagnosis}

To look into the cause of the disease and to identify the responsible spirit (the diagnosis), the beliatn listens to the long-winded reports of some family members of the patients about the history of the sicknesses ("case history", anamnesis) and about the dreams and strange encounters they have had recently.

Then, all spirits have to be lured into the room. They are supposed to settle within the altar environment and in the swing-shaped constructions with the five-color rice, the kelenkakng eboq. These efforts are made during the second and third night of a four-night belian sentiu session. On the second night, to accommodate the spirits' entering the room, the last platform in front of the house is connected with a long string of rotan wentonik to the top of the altar. On the third night a ladder-shaped connection, tukar wook (tukar= ladder), made of bete tuak (bete = leaf), the leaves of the Aren palm Arenga pinnata, (partially visible in Figure 1 and Figure 4) is added.

When the ritual starts on the third night, a heap of long branches is piled in front of the house. These are the homes to the spirits. The branches are from the eight plant species surrounding the altar and some more, like tae, Canarium sp., Burseraceae; kelebahuq, Glochidion obscurum var. macrocalyx J. J. Smith, Euphorbiaceae; kayutn arakng, Diospyros sp., Ebenaceae and nunuq ringin, Ficus benjamina L., Moraceae. Inviting bee wax torches 
light and brighten the entrance. The beliatn appears in the door taking up a polite, devote attitude, and sings, demanding that the spirits enter the room (Figure 4). After a while, the branches are laid down in front of the altar and afterwards on the altar. During this time, the beliatn are singing and performing inviting gestures. When the spirits have settled at the altar, the branches are carried out. Now, the room is teeming with spirits. Some beliatn use a swing fixed in the open door to allure the spirits to enter the room. It is called kelengkakng wook (kelengkakng $=$ swing). The fringes of the swing have to be of bete tuak, the leaves of the Aren palm Arenga pinnata.

During the third night, the diagnosis has to be established, and that means the spirit causing the disease must be identified.

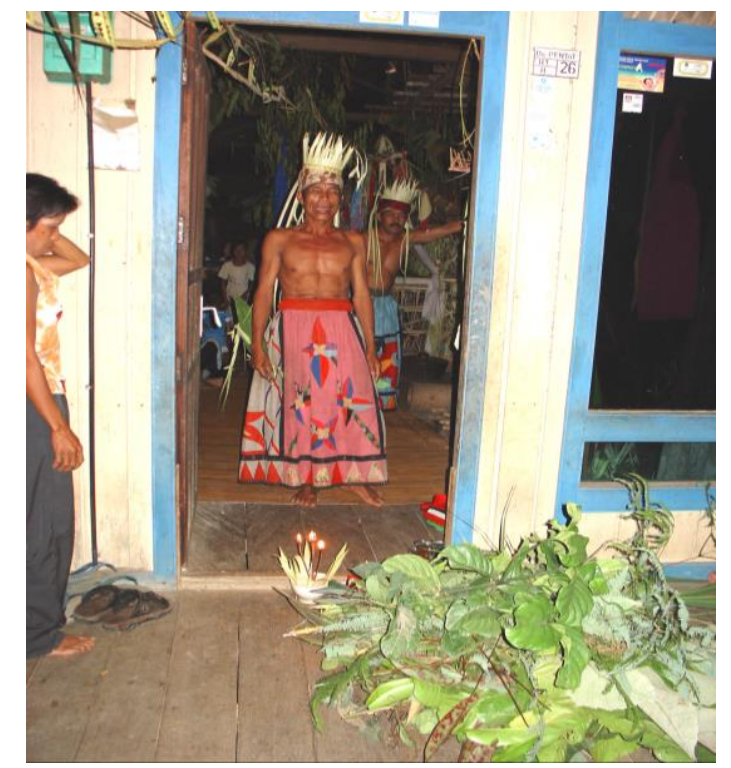

Figure 4. Inviting the spirits to enter

\section{THE RITUAL PROPHYLAXIS AND THE BLOOD SACRIFICE}

To avoid the spreading of the sickness to healthy relatives of the patient, the beliatn provides prophylactic rituals. All people present get some white rice paste (and later also blood from the sacrificed animals) rubbed onto their fronts, and fragrant "holy water" danum bungaq mayang is sprayed over them. The beliatn also keeps his "leaf sword" biowo and torches, as well as red and yellow fabrics, on hand, while singing over their heads in order to avert evil spirits.

For prophylaxis, family members also have to sit on a throne-like pantiq in front of the house. The beliatn holds a big branch of nunuq ringin, Ficus benjamina, over their head and pours a large quantity of "holy water" over branches and individuals. Nunuq ringin is the home of the kuyakng tree spirits, which can heal and influence the life span, though; they also can make people mad. The singing beliatn requests that the kuyakng provide a positive influence on the person concerned (Figure 5).

All Belian rituals afford a blood sacrifice of chickens, piaq, or pigs, uneq, and, on major occasions, even a buffalo. The offerings are the immaterial semangat and the juus of the sacrificed animal, not the body. This offering is directly dedicated to the identified spirit responsible for the malady. Then the spirit will respond with a blessing. The blood is the stuff for protecting from evil spirits and for purification. 


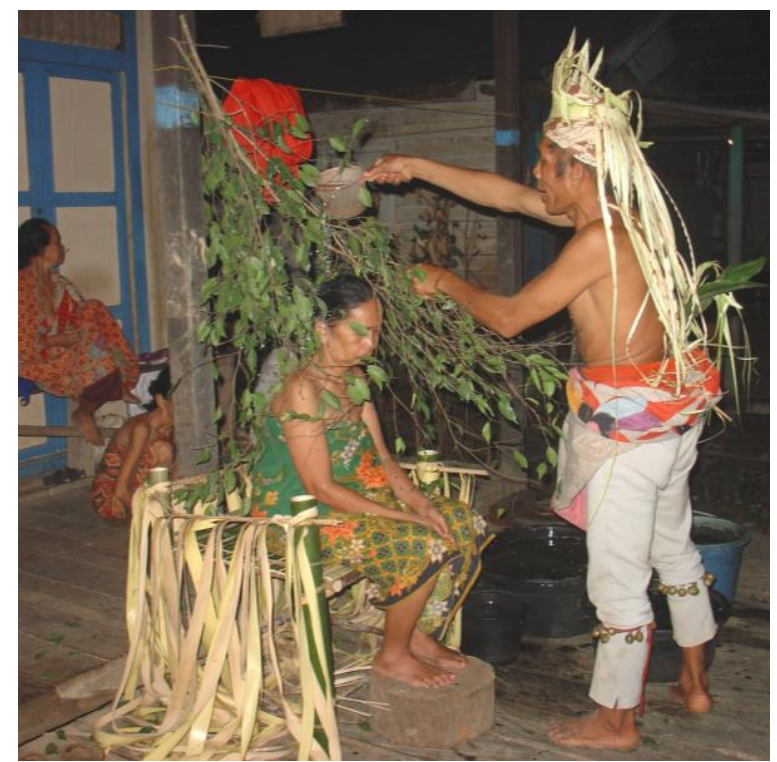

Figure 5. Beliatn Ran performing prophylaxis

After these offerings have been made, the beliatn starts to thoroughly read and judge all the parts of the sacrificed pig's liver (ate) and of the spleen (lapikng), as if they were segments of a map. When he encounters special patterns, he can distinguish messages from the spirit concerning the success of the ritual, the health of the people involved in the ritual and on future events.

\section{THE RITUAL THERAPY}

\section{(1) The Extraction of the Disease with the Telolo and its Return to the Causing Spirit Depicted in the Sepatukng Silih, the "Spittle Statue"}

The telolo is an important instrument of the beliatn in his therapy. It is a half leaf of a banana tree thinly split and bundled together on one side He puts it on the sick body part of the patient and extracts the disease with it (Figure 6). He then carefully shakes or plucks the disease from the telolo and hands it over to the blood in the bowl or to the five-color rice in the kelenkakng eboq.

However, if the illness causing spirit is already "personally" identified and the signs on the liver show that he is willing to take the disease back, then the beliatn attaches the disease directly to a statue which depicts this spirit "personally". This statue is the sepatukng silih, the "spittle statue" (silih = saliva). It is carved from potukng wood, Melicope incana.

The following describes a ritual in which two beliatn have identified the powerful tentowajak spirit as the culprit. His sepatukng silih has a pointed hat (an attribute of dangerous spirits), a face surrounded with red paint, and painted arms without hands. He is adorned with the fragrant flowers of basil. The most appalling thing about this spirit statue, however, is the painted bag hanging around his neck. With this bag, he is supposed to carry the disease back to his abode. This peculiar object, kolit sepootn, is the bag-shaped first bract (botanic prophyll) borne on the inflorescence of the Pinang palm, Areca catechu. To activate the spirit in the statue, the beliatn keeps it to the awiir and sings for a long time. 


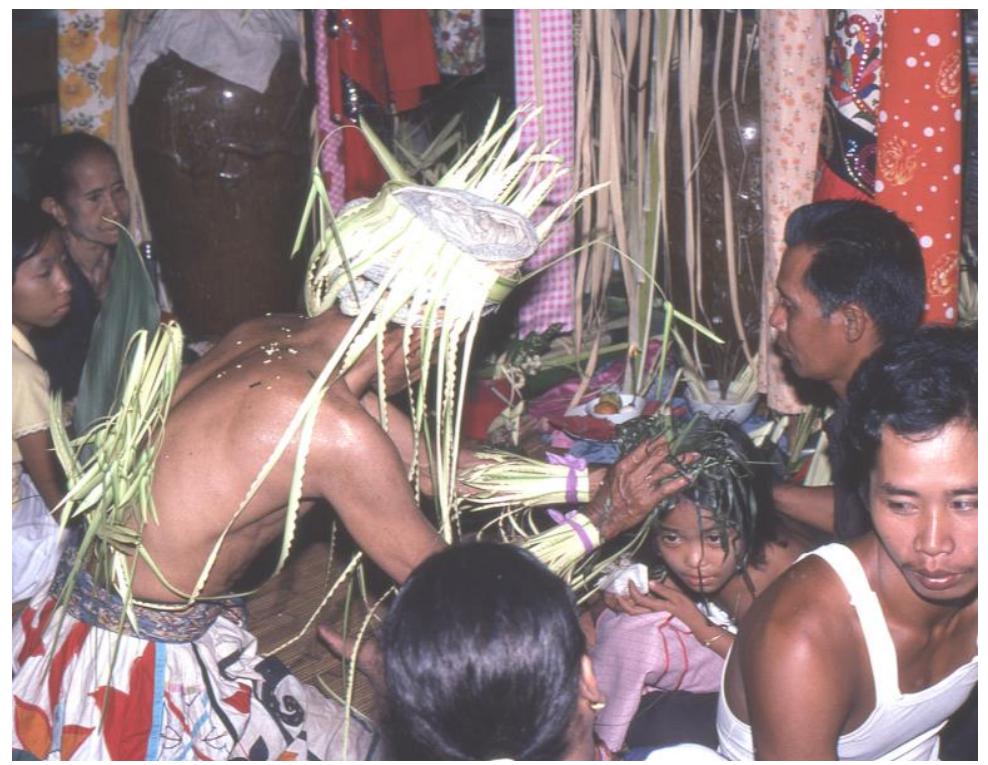

Figure 6. Extracting the disease with the Telolo

After that, the patients smear (or spit) their own saliva on/at the figure to get rid of the disease. Alternatively, the mother performs this with the saliva of her sick child (Figure 7). Moreover, the beliatn presses and rubs the telolo, with the extracted disease, on the spirit's bag to transfer the disease into it. Afterwards, somebody carries the statue with the diseases in the bag back to the forest. The Dayak Basap of the Mangkalihat Peninsula do a similar thing with their disease bearing statues (Zahorka, 2002).

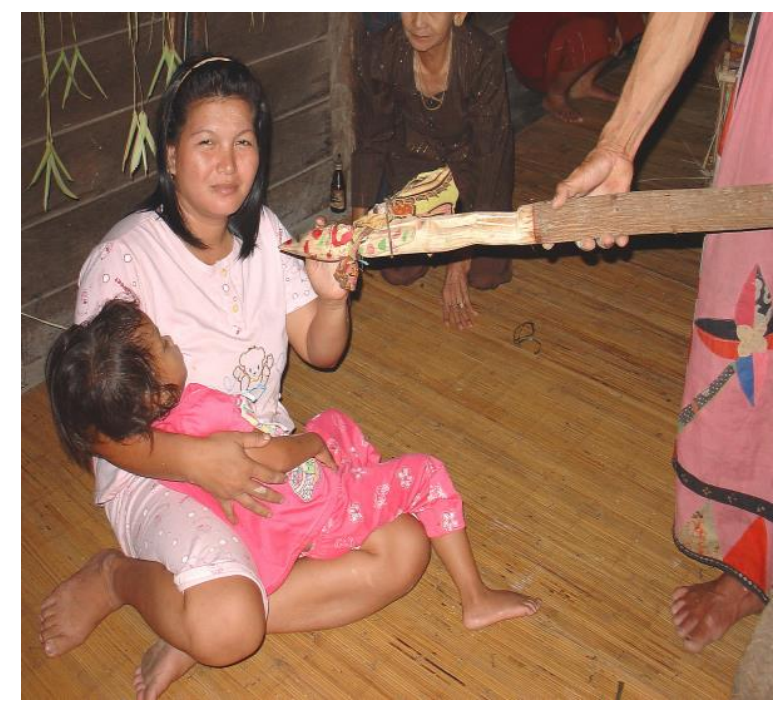

Figure 7. Saliva to be applied to the Sepatukng Silih

\section{(2) Catching the Lost Juus with the Tolakng Tintikng and its Re-implanting into the Patient's Body}

Tolakng bulaan is Bambusa vulgaris Schrader, Poaceae, and tintikng is the boiled rice inside. This is a pre-ceramic technique used to boil food. The tolakng tintikng is a piece of bamboo filled with boiled rice and often decorated at the front with coconut leaves, or blackened. It is the most important instrument of the beliatn because it acts like a magnet to the lost souls. During the third night, these objects are fixed below each rung of the ladder, 
and bundles of them, together with a fried chicken sitting on them, are kept over the heads of the patients.

At the last performance during a belian sentiu session, the beliatn dances with furious drumming and falls into a trance. The helper covers him with a fabric. This lasts at least half a minute. In this state, the spirit reveals to him the hiding place of the soul. Then the beliatn jumps up, grasps a tolakng tintikng and pokes eagerly into the spot that was revealed to him (Figure 8). This can be the branch of a plant or the bottom of a tempayan or one of the small houses for spirits as shown in the figure. Then, from the front of the bamboo stick, he pulls out a tiny thread-shaped soul and on closer examination and assessment he recognizes to which patient the soul belongs. Then, he massages the soul thoroughly into the sick body part of the concerned patient.

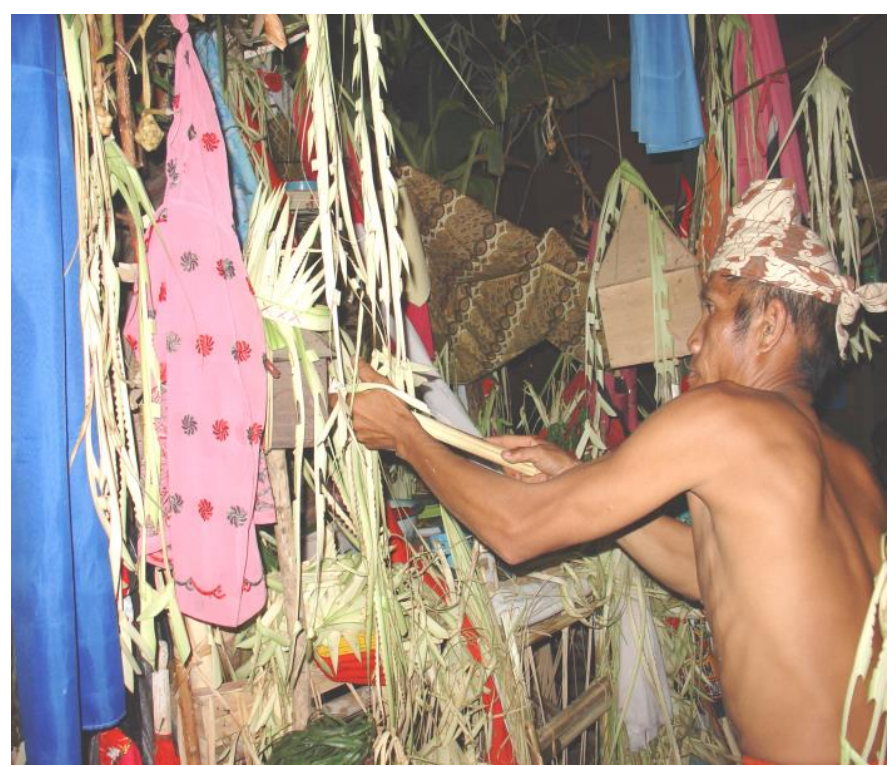

Figure 8. Soul-catching with the Tolakng Tintikng

After the disease is extracted with the telolo and the missing juus re-implanted, the patient is supposed to become healthy. The following day, after the end of the curing ritual, the crown of the beliatn is hung in front of the door indicating that the house is now tuhing, which means taboo, to nonresidents for four days.

Another healing ritual, but with much more furious dancing and drumming, is the belian bawo, which was last performed in the Lempunah longhouse in 1976 on occasion of a gugu tautn ritual (Bonoh, 1985). The historically younger belian sentiu ritual has now replaced it. The belian curing rituals of the Benuaq are shamanistic rites combining elements of medium ship, wandering and possession shamanisms (Massing, 1982; Herrmans, 2004).

\section{SOME ADDITIONAL NOTES}

The Benuaq rituals are part of their religion, which they call adat nahaa. The official Indonesian term for this traditional tribal belief is Hindu Kaharingan, but this name is unknown among the Benuaq (Weinstock, 1983). Yet, several elements of their faith are obviously related to ancient Hinduism. For example, their creator and highest spirit is Letala, etymologically most probably derived from the ancient highest Hindu authority Batara (with the Badui also Batara). Under his deity's spiritual authority, according to the myths of the 
Benuaq, are a great number of Seniang or Sangiang spirits who are responsible for the sun, the moon, the stars, the rain, the winds; they are the ancestors of the animals and of many wook. On behalf of Letala they watch over human adat and over their morals and taboos. Within this pantheon, they exist above the wook.

Another evidence of the Hindu influence on the belian rituals of the Dayak Benuaq is they do not use palm wine or other alcoholic beverages in contrast to other tribes in Kalimantan, for example the Ot Danum Dayak (Helbig, 1982) or the Tumon Dayak (Zahorka, 2001) where plenty of tuak during rituals is compulsory. Though many Benuaq are now member of Christian denominations, they still faithfully perform their rituals as a part of their cultural heritage and adat.

The payment for the beliatn is small; however, he and his helpers get the right halves of the sacrificed pig. The total expense of a four-day belian sentiu executed for two families performed by two beliatn and with two sacrificed pigs in Zahorka (2007b) was told at least IDR 6,000,000, at this time at least USD 400.

After one ritual, Beliatn Ran did something rather profane, which I would like to share here. At the end in the last night, at 3 a.m., the hosts served boiled pig meat and rice as a late dinner for all of the people present. When I got greasy fingers, Beliatn Ran, grinning, offered me his telolo as a tissue. I used it appropriately and then shook it jokingly over the bowl with the blood sacrifice; all of which drew a laugh from the gathering.

\section{ACKNOWLEDGEMENTS}

During my seven research journeys to the Benuaq Ohookng made between 1976 and 2006, my friendly and knowledgeable informants were the late Kepala Adat Dangud in Tanjung Isui, the late Kepala Adat Bakot in Lempunah and his son-in-law Anatolius Teng. The following Pembeliatn, many of them unfortunately already deceased, also introduced me into the mysteries and secrets of the Belian rituals: Angkang, Nuncutn, Daman, Moya, Rayat, Sinti, Gerong, Rantio, Iman, Kuno, Acui and Ran, many of them close friends to me. To all of them I owe deep thankfulness for allowing me to participate in their inherited plant knowledge and their shamanistic interpretation of nature and disease. My grateful acknowledgements for advices on plant identification are also given to Dr. Christian Gönner and from Herbarium Bogoriense to Dr. Harry Wiriadinata, Prof. Dr. Ir. Y. Purwanto DEA, Prof. Dr. Johannis P. Mogea, and last but not least to Dr. Ary Prihardhyanto Keim.

\section{REFERENCES}

Bonoh, Y. 1985. Belian Bawo. Departemen Pendidikan dan Kebudayaan Kantor Wilayah Propinsi Kalimantan Timur, Samarinda.

Gönner, C. 2002. A forest tribe of Borneo (Benuaq). D.K. Printworld (P) Ltd., New Delhi.

Helbig, K. 1982. Eine durchquerung der insel Borneo (Kalimantan) nach den tagebüchern ausdem jahre. Geographische Gesellschaft, Hamburg.

Herrmans, I. 2004. Representing unpredictably: An analysis of a curing ritual among the East Kalimantan Luangan. Journal of Ritual Studies 18(1): 50-61.

Massing, A.W. 1982. Where Medicine Fails: Belian Disease Prevention and Curing Rituals among the Lawangan Dayaks of East Kalimantan. Borneo Research Bulletin 14(2): $56-84$. 
Sillander, K. 1995. Ethnicity between the Luangan and the Bentian. Borneo Research Bulletin 26: 69-95.

Susiarti, S. 2005. Indigenous Knowledge on the Use of Medicinal Plants by Dayak Benuaq Society, West Kutai, East Kalimantan. Journal of Tropical Ethnobiology 2(1): 52-64.

Weinstock, J.A. 1983. Kaharingan and Luangan Dayaks: Religion and Identity in CentralEast Borneo. PhD-Thesis, Cornell University, Ithaca.

Zahorka, H. 2001. A tumon dayak burial ritual (ayah besar). Borneo Research Bulletin 32: 84-102.

Zahorka, H. 2002. A wooden figure used to take on human diseases - shamanistic healing rituals of the basap in East Kalimantan. Borneo Research Bulletin 33: 181-183.

Zahorka, H. 2007b. The shamanic belian sentiu rituals of the Benuaq Ohookng. Borneo Research Bulletin 38 127-147. 